velocity of light and the electronic charge.

Poincaré's demonstration of the necessity for discontinuities in atomic processes if the total black radiation is to remain finite has not yet been successfully questioned. If it stands, we must not only give up the hope of bringing the phenomena of physics under the sway of generalized $d y$ namics-we must renounce even the humbler ambition of describing them, in all their details, by means of differential equations. It will certainly be a triumph of the atomistic method-though unexpected and somewhat embarrassing to its most ardent supporters-if our very mathematics must become atomic.

The present state of theoretical physics is obviously one of transition, with all the discomfort that such a state involves. We are waiting for a synthesis of elements which are apparently discordant and mutually contradictory. The experience of the past forbids us to dou'bt that the necessary reconciliation will come in time; and we can foresee that it will be comparable with the greatest generalizations in the history of science. It may be that we must await the appearance of another Newton; or it may be that the result will be achieved in a more democratic manner by the cooperation of many lesser men.

H. A. Bumstead

YALE UNIVERSITY

\section{CYRILLE GRAND'EURY}

THE writer has waited some months in the hope that some one whose acquaintance was not limited to an occasional interchange of letters might publish a note of appreciation of the life and work of this savant-the last of the illustrious trio of paleobotanist, Renault, Zeiller, Grand'Eury-who made the French Carboniferous and Permian floras classic and a standard for the whole world.

François Cyrille Grand'Eury was born at Houdreville (Meurthe) on March 9, 1839. He was a mining engineer by profession and early in his oareer he became interested in the fossil plants of the Carboniferous, publishing a paper on the St. Étienne flora as early as $\mathbf{1 8 6 9 .}$ His large work on the Loire flora, a folio monograph of 624 pages and 27 plates, was published as a memoir of the French Academy in 1877 and is one of the most comprehensive works of its kind ever printed. The only other large systematic work from his pen was that on the geology and paleontology of the coalfield of the Gard published in 1890 .

Grand'Eury was always much interested in the stratigraphic applications of his subject, in the conditions of growth of the coal plants, and the origin of coal-subjects upon which he repeatedly published. He may be said to have established the chronologic succession of floras for the coal seams of the Stephanian, named from the typical development of this stage at St. Etienne. Probably no other student of Carboniferous floras had so thorough a field experience or saw one tenth the amount of material in place in the rocks as did Grand'Eury. Consequently his observations on the habit, sizes and positions of growth of the various Cordaites, Lepidophytes and Calamites are especially trustworthy. His name is inseparably associated with the elucidation of the habit and morphology of Cordaites and his restorations of these and other coal plants are to be found in every text-book.

He published a memoir upon the formation of coal in the Annales des Mines in 1882, a subject to which he returned in his paper before the International Geological Congress in 1901, and in his last large work commenced in 1912. He was not a voluminous writer and with the exception of his work on the Carboniferous plants of the Spanish peninsula, embodied in lists of species, all of his work was centered on the French floras. Nor did he, so far as I know, publish anything in the fields of Mesozoic and Cenozoic paleobotany, unless his paper of 1902 on the formation of stipite, brown coal and lignite can be so considered.

He did, however, contribute a very large 
number of short papers to the Comptes rendus of the French Academy, among which those later ones relating to the habits and seed-like fructifications in Callipteris, Neuropteris, Pecopteris and Sphenopteris are especially noteworthy. His last great work, commenced in 1912 with the collaboration of his son, one showing where his chief interest centered, was entitled "Recherches géobotaniques sur les Forêts et Sols fossiles et sur la végétation et la Flore Houillères." Influenced by his experience in the fresh-water basins of central France, he was an advocate, albeit an impartial one, of the allochthonous origin of coal beds.

He was elected to the Société Géologique in 1877 and hence was one of the oldest surviving members at the time of his death. He was elected a correspondent of the Institute in botany in the spring of 1885 . Throughout a reasonably long life he was actively engaged in mining work and was long a resident of St. Etienne, where he was an honorary professor in the School of Mines. A few years ago he removed to Malzéville, a suburb of Nancy, where he died on July 22, his death undoubtedly hastened by the untimely fate of his son on the field of battle.

In Grand'Eury science has lost another admirable representative of the French school. Of a kindly disposition, generous and courteous in all his intercourse, well informed in all he wrote, he will be sadly missed among the depleted ranks of paleobotanists among whom he labored for over half a century. With the sorrow of Zeiller's death still heavy, we have now to lay wreaths on the tombs of memory for Grand'Eury, and for his recently departed colleagues-Lignier, of Caen, and Bertrand, of Lille-would that Cuvier were still alive to fittingly pronounce their éloges.

E. W. B.

\section{SCIENTIFIC EVENTS}

ORNITHOLOGICAL FIELD WORK IN I9I7

Ir is stated in the $A u k$ that, while war conditions have necessarily curtailed activity in various directions and especially in field work, the museums have sent out expeditions and special collectors.

The Museum of Vertebrate Zoology of Berkeley devoted its attention chiefly to the southwest. H. S. Swarth visited southern Arizona and obtained material for a report on the birds found on the Apache Trail, while Grinnell and Dixon spent some time in the Death Valley region in California. In the north W. E. C. Todd was in the field five months in charge of the Carnegie Museum Expedition to northern Quebec. In tropical America the activity of previous years has decreased with the return of the American Museum Expeditions from South America but one party, comprising Messrs. Miller, Griscom and Richardson, spent four months collecting for the Museum in Nicarauga. In the West Indies, Haiti and San Domingo have been the center of attraction. W. L. Abbott, Rollo $\mathrm{H}$. Beck, and Paul Bartsch visited the islands at different times and each secured some remarkable birds or made substantial additions to our knowledge of the local avifauna. In South America Beebe spent some time at the tropical laboratory near. Georgetown, British Guiana, and Beck returned from southern Patagonia with rich collections of sea birds. From the Orient the American Museum Expedition to China, Yunnan, and northern India in charge of Roy C. Andrews returned after successfully completing its field work, and from Celebes, H. C. Raven sent some valuable collections of birds to the U. S. National Museum.

In the United States the work of the Biological Survey has been carried on with the usual activity in a number of states. In the south A. H. Howell continued his field studies of the birds of Alabama and Francis Harper visited the Okefinokee Swamp in Georgia and the everglade region in Florida. In the west H. H. T. Jackson began work on a biological survey of Wisconsin and H. C. Oberholser investigated the breeding ground of waterfowl in North Dakota. In Montana E. A. Preble collected in the southeastern part of the state south of the Northern Pacific Railroad, and Mr. and Mrs. Vernon Bailey spent some weeks studying the birds of the Glacier National 